\section{Effect of salt and drought on growth, physiological and biochemical responses of two Tamarix species}

\author{
Victoria Dawalibi ${ }^{(1)}$, Maria Cristina Monteverdi ${ }^{(2)}$, Stefano Moscatello ${ }^{(3)}$, \\ Alberto Battistelli ${ }^{(3)}$, Riccardo Valentini ${ }^{(1)}$
}

Tamarix trees are considered of particular interest for afforestation and reforestation of degraded areas prone to salinity and drought. In this study, a comparison of the performance and physiological responses of two species of Tamarix grown in saline and dried soils was carried out. Stem cuttings of $T$. aphylla and $T$. jordanis were collected from a location in the Negev desert and the plantlets obtained were subjected to four different soil treatments under semi-controlled conditions for 14 days. The treatments were: fresh water (C); salt (S: $150 \mathrm{mM}$ of $\mathrm{NaCl}$ ); drought (D: $50 \%$ field capacity); and a combined stress (DS: $150 \mathrm{mM}$ of $\mathrm{NaCl}+50 \% \mathrm{FC}$ ). Results showed a higher tolerance to salt stress of $T$. jordanis as compared with $T$. aphylla. The maintenance of high amount of cell carbohydrates, the high capacity of carbon assimilation and the active growth were considered as markers of salt tolerance in Tamarix spp. $T$. aphylla showed better performances in terms of growth and biomass production than $T$. jordanis in dry conditions. The high accumulation of sugars found in the leaves of $T$. aphylla under mild drought is considered a mechanism of acclimatization. The combined stress (salt+drought) lowered the performance of plants as compared to salt and drought stress applied alone. The possible role of the accumulation of proline observed in the leaves of both species under stressful conditions is discussed.

Keywords: Tamarix, Afforestation, Salinity, Drought, Tolerance

\section{Introduction}

Afforestation and reforestation activities have recently received high attention as measures for carbon sequestration and mitigation of climate change (Wildburger 2004). However, such activities may be complex in degraded lands where soil exhibit harsh conditions due to water shortage and salt accumulation, especially in vulnerable Mediterranean areas. The co-occurrence of the decrease in precipitation, the salinization of groundwater, and the overpopulation compelled many Mediterranean countries to look out for additional water resources (reclaimed waste water, desalinized water, etc.) in order to meet the growing demand and maintain high productivity of plants. Therefore, to face the problem of land degradation, there are increasing prospects for the use of salt and drought tolerant species showing high carbon sequestration rate and requiring minimal management practices and low production costs.

Tamarix is currently regarded as one of the species suitable to combat land degradation and mitigate climate change. This genus consists of halophytic shrubs and trees native to an area spanning from southern Europe and North Africa through the Middle East and south Asia to China and Japan (Rodman

$\square$ (1) University of Tuscia, Department of Forest Environment and Resources (DISAFRI), v. S. Camillo de Lellis snc, I-01100 Viterbo (Italy).; (2) Consiglio per la Ricerca in Agricoltura e l'Analisi dell'Economia Agraria, Forestry Research Center (CRA-SEL), v.le Santa Margherita 80, I-52100 Arezzo (Italy); (3) Institute of Agro-Environmental and Forest Biology (IBAFCNR), v.le G. Marconi 2, I-05010 Porano, Terni (Italy)

@ Victoria Dawalibi (vdawalibi@lu-forestry.net)

Received: Jan 02, 2014 - Accepted: Oct 16, 2014

Citation: Dawalibi V, Monteverdi MC, Moscatello S, Battistelli A, Valentini R, 2015. Effect of salt and drought on growth, physiological and biochemical responses of two Tamarix species. iForest 8: 772-779 [online 2015-03-25] URL: http://www.sisef.it/iforest/contents/? id=ifor $1233-007$

Communicated by: Silvano Fares

1990). Tamarix plants are of particular interest for their fast growth, easy vegetative propagation and acclimatability to a wide range of contrasting environmental conditions (Brotherson \& Field 1987). Tamarix shows various protective mechanisms allowing its survival and growth in harsh environments, including the presence of salt glands on leaves (Waisel 1972, Metcalfe \& Chalk 1950, McClintock 1951), which play an important role in regulating ionic balance (Ramadan 1998) and maintaining/stabilizing osmotic and turgor pressure under high salinity (Ding et al. 2009). Indeed, such glands may excrete the salt excess which accumulates in the tissue through transpiration (Scholander et al. 1964, 1965). Previous studies have also investigated the biochemical responses of Tamarix spp. under different levels of salt stress (Solomon et al. 1994, Jones et al. 1995, 2005). Tamarix jordanis Boiss has been reported to contain proline analogues that can reduce the negative effects of $\mathrm{NaCl}$ on the RuBisCO activity (Solomon et al. 1994). In addition, proline has been reported to accumulate in roots of Tamarix tetragyna Ehrenb with increasing salinity up to $480 \mathrm{mM}$ (Bar-Nun \& Poljakoff 1977).

The ability of Tamarix to closely regulate photosynthesis and leaf conductance during drought increases its survivability and competitiveness in arid and semiarid rangelands (Mounsif et al. 2002). According to Frasier \& Johnsen (1991), Tamarix spp. are well adapted for survival in arid and semi-arid climates, and may tolerate even dramatic changes in soil moisture after establishment, provided that groundwater is available. Tamarix has a deep, extensive root system very efficient in accessing limited water supplies, and has higher water-use efficiency than native riparian (Zlatnik 1999). While the role of metabolites such as soluble sugars (sucrose, glucose and fructose) in conferring drought tolerance is well documented for many plants (Crowe et al. 1990, Vertucci \& Farrant 1995, Hoekstra et al. 2001), little is known about the accumulation of osmolytes and their role in drought tolerance of Tamarix spp.

Approximately 54 species of Tamarix spp. have been described worldwide (Baum 1978), which may differ in their tolerance to salt and drought stress. However, few studies compared their performance under different harsh conditions. Thus, understanding how Tamarix spp. respond to the combined effect of drought and salt stresses may contribute to the selection of the best material to be used for biomass production and conservation purposes in arid zones. This study aims to evaluate the effects of salinity, drought stress and their combination on growth rate, biomass and gas exchange of two Tamarix 
species, as well as on their carbohydrate and proline content.

\section{Material and methods}

\section{Plant material and culture conditions}

Stem cuttings of two species of Tamarix, T. aphylla (L.) Karst and T. jordanis Boiss, were collected from a plantation located in the Negev Desert (southern Israel - 31 $30^{\circ}$ $56.01^{\prime \prime} \mathrm{N}, 34^{\circ} 26^{\prime} 59.62^{\prime \prime}$ E). Average annual rainfall at the sampling site was less than $100 \mathrm{~mm} \mathrm{yr}^{-1}$ and summer average temperature between 32 and $39{ }^{\circ} \mathrm{C}$. One year old stem cuttings (diameter: 7-9 mm, length: 20 $\mathrm{cm}$ ) were planted in pots of $24 \mathrm{~cm}$ in diameter with drain holes filled with sandy soil. After rooting of cuttings, plants showing homogeneous development and size were selected, transplanted and acclimatized in a greenhouse for 14 days. Each species was then submitted to four different treatments, each including seven replicates, totaling 112 plants (28 individuals per species per treatment). The first treatment was irrigated with fresh water $(\mathrm{C})$, the second with saline water $150 \mathrm{mM}(\mathrm{S})$, the third (D) was irrigated to $50 \%$ of field capacity (FC), and the fourth with saline water $150 \mathrm{mM}$ to $50 \% \mathrm{FC}$ (DS). Pots were covered with plastic film to minimize evaporation. Four pots with no plants were used as a control to monitor the evaporative loss from the soil surface. Plants were then grown in a greenhouse for 14 days. All the plants received periodically the same quantity of nutrients. Water content was monitored gravimetrically every night by weighing the pots, and water level (measured as weight) was adjusted relative to the FC level needed. Electrical conductivity (EC) of the drained liquid phase was measured daily in the morning after irrigation, using a conductimeter (HI9811, Hanna instruments INC, USA) equipped with an electrode probe (HI1285, Hanna instruments INC, USA). Salt concentration in the soil was assessed by collecting a soil core at $20 \mathrm{~cm}$ depth, and then measuring the electrical conductivity of the saturated soil extract ECe. Electrical conductivity was expressed as ds $\mathrm{m}^{-1}$, ranging for both species from 0.9 to $1 \mathrm{ds}$ $\mathrm{m}^{-1}$ for treatment $\mathrm{C}, 1-1.33 \mathrm{ds} \mathrm{m}^{-1}$ for treatment D 14.8-15.6 $\mathrm{ds} \mathrm{m}^{-1}$ for treatment $\mathrm{S}$ and $15-18 \mathrm{ds} \mathrm{m}^{-1}$ for treatment DS.

\section{Growth measurements}

Plant growth was monitored at the beginning, at the midpoint and at the end of the experiment by measuring the increment in plant height. At the end of the experiment, plants were divided into leaves, stems and roots and their respective fresh weight $(\mathrm{FW})$ was determined. Dry weight (DW) was obtained by oven drying at $70{ }^{\circ} \mathrm{C}$ until a constant weight was reached.

\section{Gas exchange measurements}

Net assimilation of $\mathrm{CO}_{2}(A)$, stomatal conductance $\left(g_{\mathrm{s}}\right)$ and transpiration rate $(E)$ were measured at the beginning, midway and at the end of the experiment using a portable photosynthesis system (LI-6400) equipped with a conifer chamber. The intrinsic water use efficiency (WUE) was obtained as the ratio between net assimilation and stomatal conductance $\left(A / g_{\mathrm{s}}\right)$.

All measurements were made in the morning from 9:30 to 13:00 $\mathrm{h}$, on a green twig of about $5 \mathrm{~cm}^{2}$ selected in the middle part of the plant. Measurement conditions were as follows: $1800 \mu \mathrm{mol} \mathrm{m}^{-2} \mathrm{~s}^{-1}$ photosynthetically active radiation (PAR), $400 \mu \mathrm{mol} \mathrm{mol}{ }^{-1} \mathrm{am}-$ bient $\mathrm{CO}_{2}$ concentration, and $28 \pm 2{ }^{\circ} \mathrm{C}$ leaf temperature. Data were automatically recorded after stabilization of the photosynthesis rate.

\section{Carbohydrates analysis}

Fresh leaf tissue was finely ground using liquid nitrogen, and $40 \mathrm{mg}$ of ground tissue were extracted with $1.5 \mathrm{ml}$ of $80 \%$ ethanol and $20 \%$ buffer (Hepes $100 \mathrm{mM}, \mathrm{pH} 7.1$, $\mathrm{MgCl}_{2} 10 \mathrm{mM}$ ) at $80{ }^{\circ} \mathrm{C}$ for $45 \mathrm{~min}$. After cooling and centrifugation at $13000 \mathrm{~g}$ for 5 $\mathrm{min}$, the supernatant was collected for quantification of soluble sugars, while the pellet was used for the determination of the starch content. Soluble sugars were measured using enzymatic assays as described by Moscatello et al. (2011). Sugar determination assays were performed using an Anthos plate reader (Anthos Labtec Instruments, Wals, Austria) in dual-wavelength mode $(340-405 \mathrm{~nm})$. The endpoint determination for all sugars (glucose, fructose and sucrose) was based on the reduction of $\mathrm{NAD}^{+}$to NADH. Glucose was determined by first converting to glucose-6phosphate in the presence of $100 \mathrm{mM}$ Hepes (KOH - pH 7.1), $10 \mathrm{mM} \mathrm{MgCl}_{2}, 1 \mathrm{mM}$ DTT, $0.02 \%$ BSA, ATP $100 \mathrm{mM}, \mathrm{NAD}^{+} 80 \mathrm{mM}$ and hexokinase $0.5 \mathrm{U}$, and then measuring its reduction of $\mathrm{NAD}^{+}$in the presence of glucose-6-phosphate dehydrogenase $0.3 \mathrm{U}$. Absorbance by NADH was read at $340 \mathrm{~nm}$. Fructose was phosphorylated as for glucose, converted to glucose-6-phosphate with phosphoglucoisomerase $0.3 \mathrm{U}$, and then assayed as for glucose. Sucrose was hydrolyzed with invertase $50 \mathrm{U}$, and glucose and fructose released by hydrolysis were assayed as described above. The pellet was washed three times with sodium acetate $50 \mathrm{mM} \mathrm{pH} 4.6$, autoclaved with $1 \mathrm{ml}$ sodium acetate for one hour at $120{ }^{\circ} \mathrm{C}$, and then hydrolyzed by adding $70 \mathrm{U}$ amyloglucosidase and $4 \mathrm{U} \alpha$ amylase. The obtained suspension was incubated at $50{ }^{\circ} \mathrm{C}$ for one hour with regular shaking. Following centrifugation at 13000 $g$, the glucose released in the supernatant was used for starch quantification as in the aforementioned assay.

\section{Proline analysis}

Free proline content was estimated following the method of Bates (1973). Fresh leaves $(0.5 \mathrm{~g})$ were extracted in 3\% sulphosalicylic acid, and the homogenates obtained were centrifuged at $10000 \mathrm{~g}$ for $10 \mathrm{~min}$. A 2 $\mathrm{ml}$ of the supernatant was reacted with $2 \mathrm{ml}$ of acid ninhydrin reagent and $2 \mathrm{ml}$ of glacial acetic acid in a test tube for one hour at 100 ${ }^{\circ} \mathrm{C}$ and the reaction was terminated in an ice bath. The reaction mixture was extracted with $4 \mathrm{ml}$ of toluene and mixed vigorously with a vortex mixture for $15-20 \mathrm{~s}$. The chromophore containing toluene was aspirated from the aqueous phase, warmed to room temperature and the absorbance measured at $510 \mathrm{~nm}$ using toluene as blank. Proline concentration was calculated from a standard curve using 0-100 $\mu \mathrm{g} \mathrm{l}^{-1}$ proline $\left(\operatorname{Sigma}^{\circledR}\right)$.

\section{Greenhouse conditions}

Temperature and humidity inside the greenhouse were monitored daily throughout the period of the experiment. The mean temperature ranged between 22.02 and 27.32 ${ }^{\circ} \mathrm{C}$, while mean relative humidity ranged between 37.8 and $73.9 \%$. The observed lowest values of relative humidity were attained only around the $7^{\text {th }}$ day of the experiment $(37.8 \%)$.

\section{Experimental design and statistical analysis}

A completely randomized design was used. Due to destructive nature of the analyses carried out, seven replicates of plant height increment data and four replicates for all other measurements were used. Means were submitted to the analysis of variance and tested using a least significant difference (LSD) test $(\alpha=0.05)$. When a significant difference (P $\leq 0.05)$ was detected, mean values were compared using the Duncan's multiple range test. Factorial analysis was used to test for inter-specific differences induced by the treatment, and repeated measures ANOVA to test for the time effect. All statistical analyses and computations were carried out using the software package STATISTICA ${ }^{\circledR}$ for Windows version 7.0.61 (StatSoft, Tulsa, OK, USA).

\section{Results}

\section{Growth measurements}

At the end of the experiment, T. aphylla and $T$. jordanis showed different growth responses depending the applied stress. Salt had a highly negative effect on plant height increment of $T$. aphylla, which was reduced by $27.3 \%$, while it did not show any significant effect on $T$. jordanis (Tab. 1). The shoot dry weight of both species was not negatively affected by salt stress in the short period of the experiment, yet shoot dry weight of $T$. jordanis under salt stress was even 
Tab. 1 - Height increment, shoot, root weight and root/shoot ratio of T. aphylla and T. jordanis plants exposed to stress. Treatments: (C) Control; (S) salt (150 mM); (D) drought (50\% FC); (DS) drought + salt (150 mM + 50\% FC). Different letters indicate statistically different means $(\mathrm{P} \leq 0.05)$ at the $14^{\text {th }}$ day after the Duncan's multiple range test. Data of plant height increment are means of seven replicates \pm standard error. Data of shoots dry mass, root dry mass and root/shoot ratio are means of four replicates \pm standard error.

\begin{tabular}{|c|c|c|c|c|c|}
\hline Species & Treatment & $\begin{array}{l}\text { Plant height increment } \\
\text { (cm/14 days) }\end{array}$ & $\begin{array}{c}\text { Shoots dry mass } \\
\left(\text { g plant }^{-1}\right)\end{array}$ & $\begin{array}{l}\text { Root dry mass } \\
\left(\text { g plant }^{-1}\right)\end{array}$ & $\begin{array}{l}\text { Root/shoot } \\
\text { ratio }\end{array}$ \\
\hline \multirow[t]{4}{*}{ T. aphylla } & $\mathrm{C}$ & $0.73 \pm 0.06^{\mathrm{a}}$ & $41.45 \pm 4.37^{\mathrm{a}}$ & $20.37 \pm 2.55^{\mathrm{a}}$ & $0.49 \pm 0.02^{\mathrm{b}}$ \\
\hline & S & $0.53 \pm 0.05^{\mathrm{b}}$ & $42.95 \pm 5.62^{\mathrm{a}}$ & $21.38 \pm 2.35^{\mathrm{a}}$ & $0.50 \pm 0.03^{b}$ \\
\hline & $\mathrm{D}$ & $0.52 \pm 0.05^{b}$ & $33.65 \pm 2.94^{\mathrm{ab}}$ & $20.92 \pm 1.50^{\mathrm{a}}$ & $0.63 \pm 0.03^{\mathrm{ab}}$ \\
\hline & DS & $0.11 \pm 0.01^{\mathrm{c}}$ & $26.84 \pm 4.45^{b}$ & $21.06 \pm 3.68^{\mathrm{a}}$ & $0.85 \pm 0.17^{\mathrm{a}}$ \\
\hline \multirow[t]{4}{*}{ T. jordanis } & $\mathrm{C}$ & $1.10 \pm 0.16^{\mathrm{a}}$ & $66.00 \pm 7.74^{\mathrm{a}}$ & $30.19 \pm 2.13^{\mathrm{a}}$ & $0.47 \pm 0.04^{\mathrm{b}}$ \\
\hline & S & $1.12 \pm 0.25^{\mathrm{a}}$ & $77.10 \pm 2.46^{\mathrm{a}}$ & $29.20 \pm 4.47^{\mathrm{a}}$ & $0.45 \pm 0.05^{\mathrm{b}}$ \\
\hline & $\mathrm{D}$ & $0.49 \pm 0.08^{b}$ & $44.49 \pm 4.57^{b}$ & $35.85 \pm 1.22^{\mathrm{a}}$ & $0.84 \pm 0.10^{\mathrm{a}}$ \\
\hline & DS & $0.26 \pm 0.05^{\mathrm{b}}$ & $44.96 \pm 4.78^{b}$ & $26.98 \pm 1.35^{\mathrm{a}}$ & $0.61 \pm 0.05^{\mathrm{b}}$ \\
\hline
\end{tabular}

higher than the control (Tab. 1). Similarly, roots of both species were not affected by salt stress.

Contrastingly, drought $(50 \% \mathrm{FC})$ showed an opposite impact on Tamarix spp., determining a severe reduction of plant height increment by $55 \%$ in $T$. jordanis vs. only $28.7 \%$ in T. aphylla. Reduction of shoot dry weight observed in the drought treatment $(50 \% \mathrm{FC})$ was also severe for $T$. jordanis, (32.5\%), and non significant for T. aphylla (19\% - Tab. 1). Consequently, a higher root/ shoot ratio was recorded in $T$. jordanis, while non-significant changes of root/shoot ratio were detected in T. aphylla (Tab. 1).

The combination of both stress (treatment DS) had the most pronounced effect on plant growth of both species. On the third day of experiment, symptoms of leaf yellowness and shedding were detected at the bottom part of plants and were more pronounced for $T$. aphylla than for $T$. jordanis. At the end of experiment, height increment of $T$. aphylla and $T$. jordanis plants was strongly influenced by the combined stress, with a significant decrease by $85 \%$ and $76.3 \%$, respectively, as compared with control plants (Tab. 1 ). In the combined stress treatment (DS), shoot dry weight of $T$. aphylla and $T$. jordanis plants were significantly lower than control plants by $35.4 \%$ and $31.8 \%$, respectively. Root dry weight was not affected by the combined stress in both species (Tab. 1). The root/ shoot ratio of $T$. aphylla plants grown under the combined stress was significantly higher $(73.5 \%)$ than that of control plants, while no significant differences were observed in root/ shoot ratio between $T$. jordanis and control plants.

\section{Gas exchange measurements}

Absolute differences in the mean of carbon assimilation capacity $(A)$, stomatal conductance $\left(g_{\mathrm{s}}\right)$, and transpiration rate $(E)$ were observed between $T$. aphylla and $T$. jordanis plants. Generally, the highest values of $A, g_{\mathrm{s}}$ and $E$ throughout the experiment were recor-

\section{T. aphylla}

A

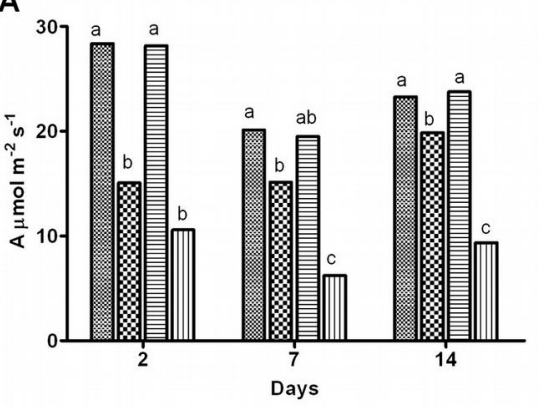

C

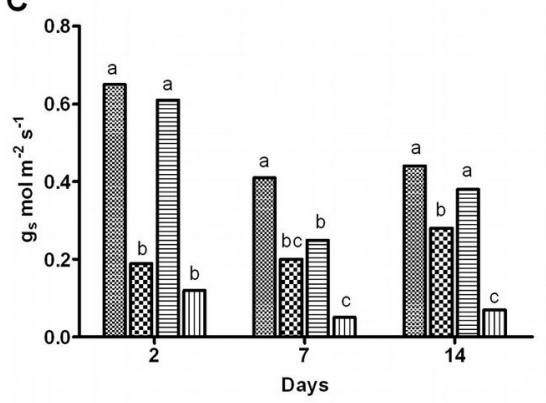

E

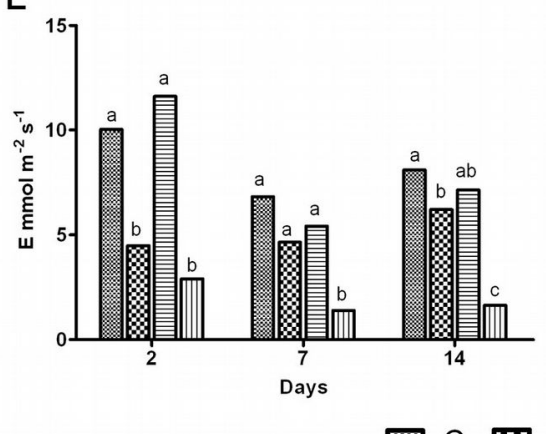

T. Jordanis

B

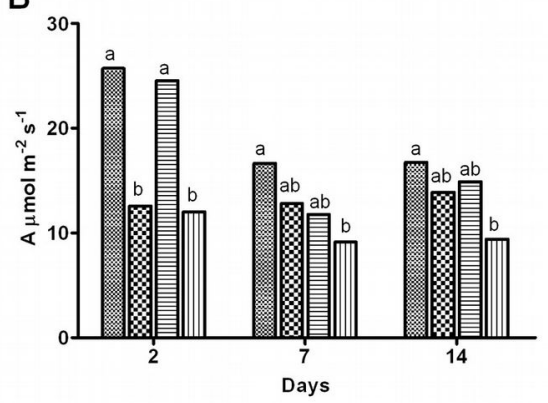

D

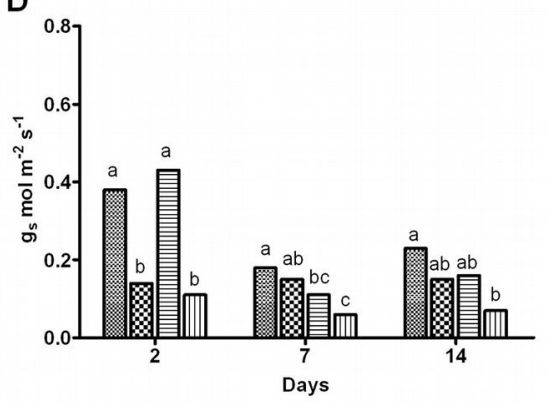

F

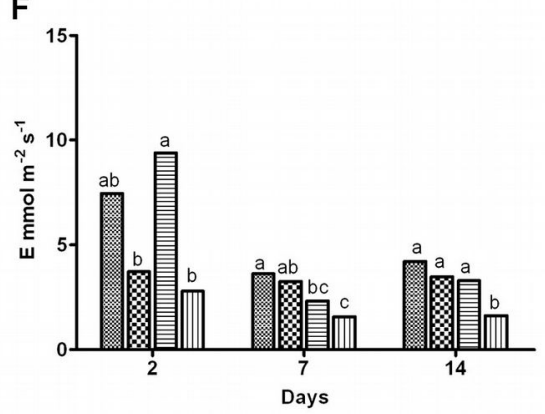

Fig. 1 - Gas exchange measurements of T. aphylla (A, C, E) and T. jordanis $(\mathrm{B}, \mathrm{D}, \mathrm{F})$ plants exposed to different stress treatments. $(A)$ : assimilation rate (panels A-B); $\left(g_{\mathrm{s}}\right)$ : stomatal conductance (panels C-D); $(E)$ : transpiration rate (panels E-F); (C): Control; $(\mathrm{S})$ : salt (150 mM); (D): drought ( $50 \%$ FC); (DS): drought + salt (150 mM +50\% FC). Data are means of four replicates. Different letters at the top of bars indicate statistically different means $(\mathrm{P} \leq 0.05)$ after the Duncan's multiple range test. 
ded for $T$. aphylla, with values higher by $21 \%, 43.7 \%$ and $25.2 \%$, respectively, as compared with $T$. jordanis plants (Fig. 1). Salinity (S) and the combination of drought and salt stress (DS) did affect $A, g_{\mathrm{s}}$ and $E$ in both species to a higher extent than drought alone (D).

On the $2^{\text {nd }}$ day, salt $(150 \mathrm{mM})$ reduced significantly $A, g_{\mathrm{s}}$ and $E$ relative to the control (p $\leq 0.05$ ) by $46.9 \%, 70.3 \%, 55 \%$ in $T$. aphylla, and by $51.1 \%, 62.6 \%, 50 \%$ in $T$. jordanis, respectively. Afterwards, both species showed an improvement of such parameters on the $7^{\text {th }}$ day and a full restoration on the $14^{\text {th }}$ day as compared with untreated plants. However, a better improvement of these parameters was achieved by $T$. jordanis plants. Indeed, reductions of $A, g_{\mathrm{s}}$ and $E$ in $T$. jordanis plants were no longer significantly different from controls on day 14 , while $T$. aphylla plants showed a significant reduction of $A, g_{\mathrm{s}}$ and $E$ (by $14.7 \%, 36 \%$, $23.3 \%$, respectively - Fig. 1).

Drought $(50 \% \mathrm{FC})$ effects on $A, g_{\mathrm{s}}$ and $E$ were minimal over the experiment in both species, as compared with salt stress. Only on the $7^{\text {th }}$ day, water deficit $(50 \% \mathrm{FC})$ determined some alterations of $g_{\mathrm{s}}$ and $E$ (Fig. 1CF), while had no significant effect on $A$ (Fig. 1A-B).

Plants subjected to the combined salt and drought stress (DS) had the most affected values of gas exchange among all treatments and throughout the 14 days of the experiment (Fig. 1). Unlike plants exposed to the salt stress alone (treatment $\mathrm{S}$ ), both species grown under the combined stress (DS) did not achieve any significant improvement during the experiment. At the end of the experiment, $A$ was significantly lower than control in T. aphylla (59.8\%) and T. jordanis $(43.7 \%, \mathrm{p} \leq 0.05$ - Fig. 1A-B).

\section{Water use efficiency}

Factorial analysis revealed that the intrinsic water use efficiency $\left(W U E=A / g_{\mathrm{s}}\right)$ was generally higher in $T$. jordanis than in T. aphylla, regardless of the stress applied $(\mathrm{p} \leq 0.05$ Fig. 2), due to its relatively low values of $g_{\mathrm{s}}$ (Fig. 1C-D). Overall, a certain increase in the ratio $A / g_{\mathrm{s}}$ was recorded in all treatments for both Tamarix species, as compared with the control plants.

As for the salt stress treatment (S), WUE increased during the experiment in both species. T. aphylla plants showed a significant increase $(44.15 \%)$ in WUE since the second day, while in T. jordanis WUE increased only at the end of the experiment (Fig. 2).

Under drought stress (treatment D), $T$. aphylla plants showed some fluctuations of $W U E$ over the experiment, with an observed increase of $31.3 \%$, while $W U E$ values in $T$. jordanis increased only in the last experimental stage (Fig. 2). Contrastingly, both species had the highest $W U E$ values in the combined treatment (Fig. 2), with higher increments in $T$. aphylla than in $T$. jordanis over the trial period $(\mathrm{p} \leq 0.05)$.

\section{Sugars}

Leaf sugar content was affected by stress in both species, showing similar sugar trend responses with slight differences and a marked response in T. aphylla.

Under salt stress (S), a drastic reduction of glucose $(51 \%)$ and fructose $(41.5 \%)$ content was detected on the $2^{\text {nd }}$ day in T. aphylla plants. Afterwards, glucose and fructose content recovered in the leaves of $T$. aphylla on the $7^{\text {th }}$ day. Nonetheless, at the end of the experiment the content of both sugars resulted significantly lower in treated plants than in control plants. On the other hand, from the $2^{\text {nd }}$ to the $14^{\text {th }}$ day, the reduction in content of glucose and fructose was not significant for $T$. jordanis plants subjected to salt stress (150 mM - Fig. 3A-D).

Salt stress treatment (S) did not affect sucrose content in both species (Fig. 3E-F), while caused a decline of starch content in both species. In T. aphylla, starch was highly affected by salt stress, decreasing sharply by $49.7 \%$ on the $2^{\text {nd }}$ day, while $T$. jordanis showed a non significant reduction of starch content. However, a recovery in starch content in $T$. aphylla and T. jordanis was noticed in the following days (Fig. 4).

Under drought stress (treatment D), the substantial difference in soluble sugar content was evident only at the $7^{\text {th }}$ day. Accumu- lation of all soluble sugars (glucose, fructose and sucrose) was significantly higher than the control only for T. aphylla leaves (Fig. $3)$. Drought $(50 \%$ FC) provoked an initial significant decrease in starch content of $T$. jordanis leaves and did not influence starch level in T. aphylla leaves. However, a lower starch content was detected on the $7^{\text {th }}$ day in both species $(37 \%$ in T. aphylla and $44 \%$ in $T$. jordanis) as compared with control plants, partly balanced by an increase in soluble sugars in the leaves of both species. Afterwards, starch content fairly increased in both species under drought (D), equaling the control plant values (Fig. 4).

Combined stress (DS) initially induced a reduction in glucose and fructose in both species. Glucose was reduced by $56 \%$ in $T$. aphylla and by $46 \%$ in $T$. jordanis, while fructose was reduced by $44 \%$ in $T$. aphylla and by $31 \%$ in $T$. jordanis, as compared with the control plants (Fig. 3A-D). At the end of treatment, the combined stress treatment (DS) showed the same effect of the salt treatment (S) on glucose and fructose (Fig. 3AD). Unlike hexose sugars, sucrose was stable throughout the whole experiment, being values for all treated plants not significantly different from those of the control plants (Fig. 3E-F). The combined stress significantly reduced the starch content relative to the control in both species, with an estimated reduction at the $2^{\text {nd }}$ day between $49.7 \%$ and $61.3 \%$ in $T$. jordanis and T. aphylla, respectively. The last day of experiment, starch content of plants grown under combined stress (DS) was significantly lower than the control $64.2 \%, 74.2 \%$ in $T$. jordanis and $T$. aphylla, respectively (Fig. 4). The starch response under the combined stress was similar to that described for the salt stress treatment at the beginning, though at the end of the experiment clear differences from $\mathrm{S}$ and D treatments were observed (Fig. 4).

\section{Proline}

In general, $T$. aphylla accumulated larger quantity of proline than $T$. jordanis. Salt stress induced an accumulation of proline in the second day only in T. aphylla. Neither species showed any significant response in

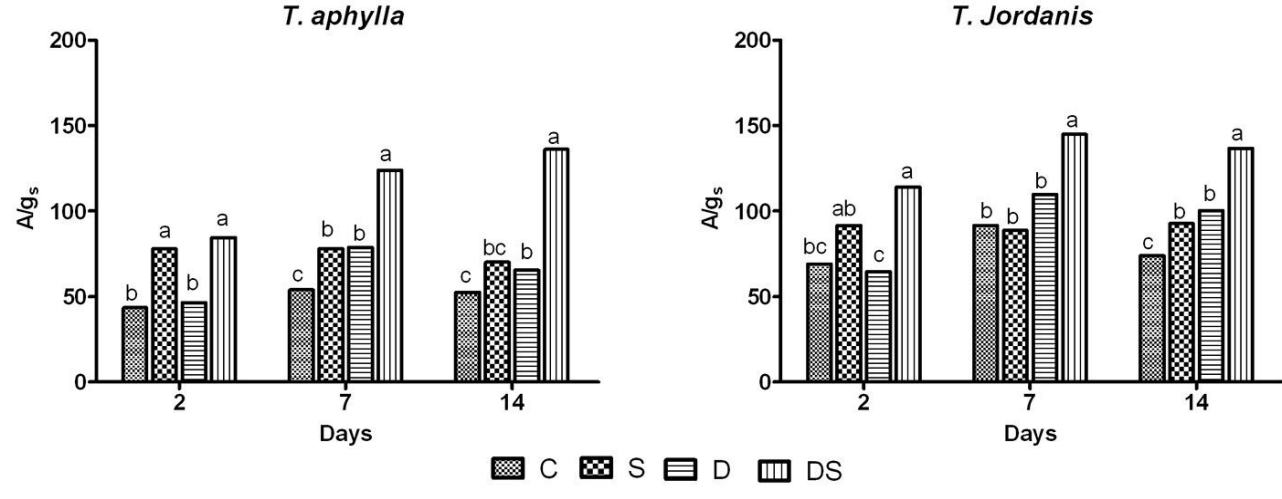

Fig. 2 - Water use efficiency $\left(A / g_{\mathrm{s}}\right)$ of T. aphylla and T. jordanis plants under different stress treatments. (C): Control; (S): salt (150 mM); (D): drought (50\% FC); (DS): drought + salt $(150 \mathrm{mM}+50 \%$ FC). Data are means of four replicates. Different letters on the top of the error bars indicate statistically different means ( $P$ $\leq 0.05$ ) after the Duncan's multiple range test. 
Fig. 3 - Soluble sugar content (glucose: A-B, fructose: C-D; and sucrose: E-F) of T. aphylla

and $T$. jordanis plants exposed to different stress treatments. (C): Control; (S): salt (150 salt $(150 \mathrm{mM}+50 \% \mathrm{FC})$. Data are means of four replicates. Different letters on the top of bars indicate statistically different means $(\mathrm{P} \leq$ $0.05)$ after the Duncan's multiple range test. $\mathrm{mM})$; (D): drought (50\% FC); (DS): drought +
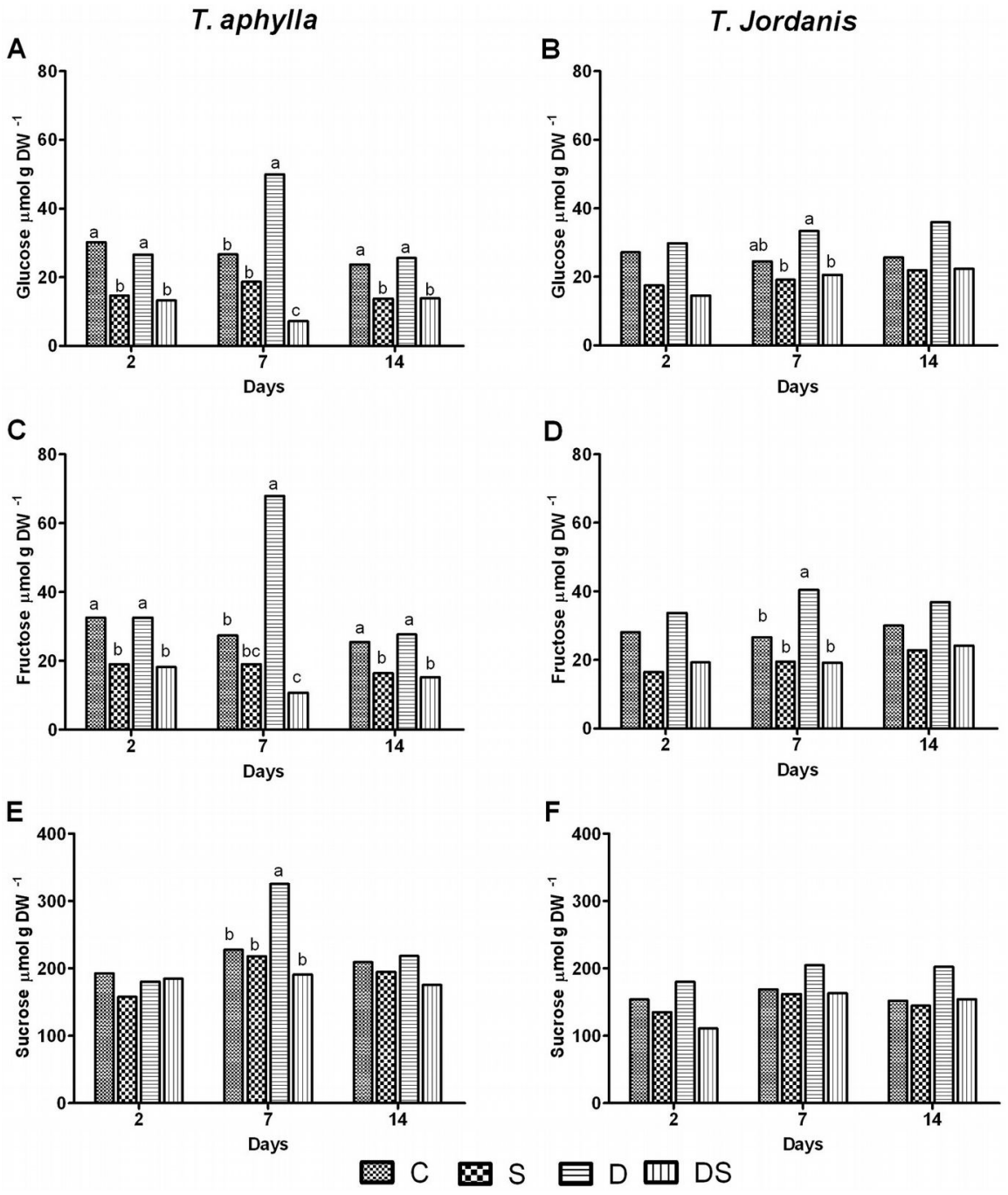

Fig. 4 - Starch content of T. aphylla and $T$. jordanis plants exposed to different stress treatments. (C): Control;

(S): salt (150 mM); (D): drought (50\% FC); (DS): drought + salt (150 $\mathrm{mM}+50 \%$ FC). Data are means of four replicates. Different letters on the top of bars indicate statistically different means $(\mathrm{P} \leq 0.05)$ after the Duncan's multiple range test.

Fig. 5 - Proline content of T. aphylla and $T$. jordanis plants exposed to different stress treatments. (C): Control;

(S): salt (150 mM); (D): drought (50\% FC); (DS): drought + salt (150 $\mathrm{mM}+50 \% \mathrm{FC}$ ). Data are means of four replicates. Different letters on the top of bars indicate statistically different means $(\mathrm{P} \leq 0.05)$ after the Duncan's multiple range test.

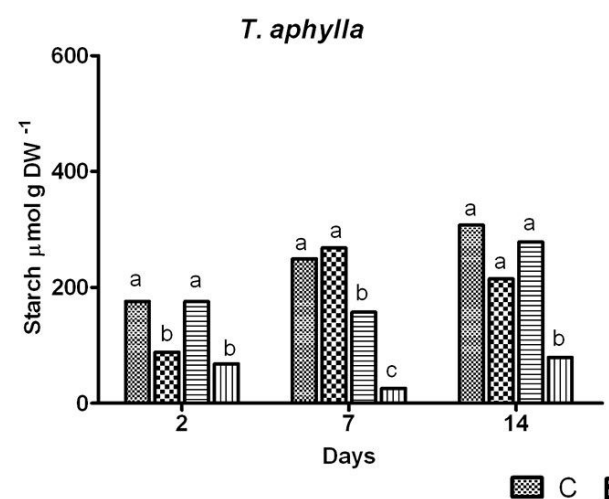

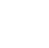
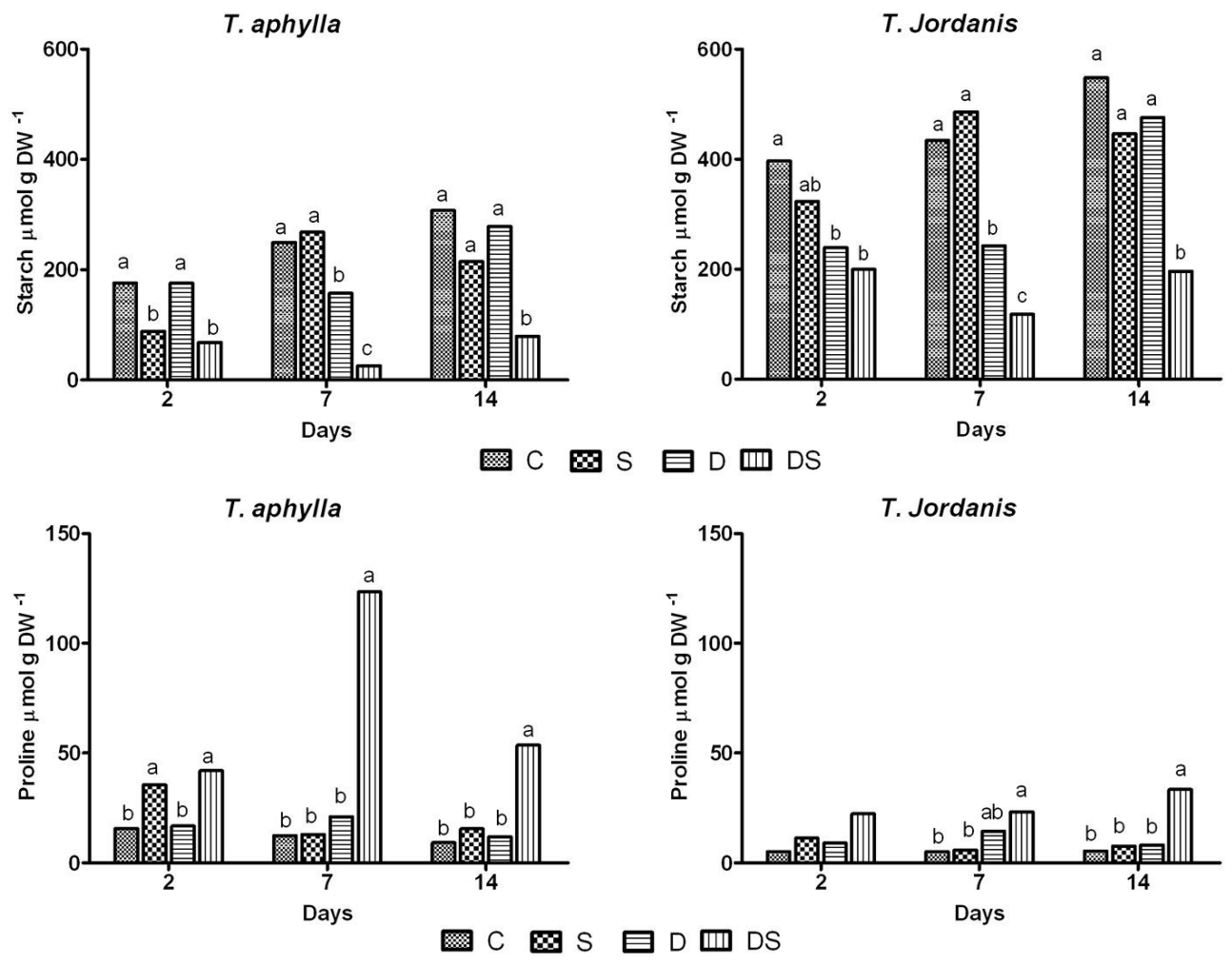
proline accumulation under water deficit For both species proline accumulation was higher for plants under treatment DS (combined stress), with the free proline content increasing approximately 5-9 fold as compared with the control plants (Fig. 5).

\section{Discussion}

Tamarix plants are halophytes that can acclimate and grow under high salinity levels, surviving in areas where the groundwater concentration of dissolved solids reaches 15000 ppm (Waisel 1972, Carman \& Brotherson 1982). This tolerance to saline soil is achieved mainly by special salt excreting glands (Waisel 1961, Kozlowski 1997).

In this study, submission of two different Tamarix species to salt stress $(150 \mathrm{mM})$ induced notable changes on physiological responses and growth of both species relative to plants grown under control conditions. The yellowing and shedding of old leaves observed in both species during the experiment suggest that toxic ions could accumulate in the oldest leaves, preventing the death of younger ones. Such symptoms appeared earlier and more severely in T. aphylla, indicating its lower ability in partitioning toxic ions in the vacuoles, and therefore a lower salt tolerance as compared with $T$. jordanis Storage of salt in old leaves probably occurs via the absorption of incoming ions from the xylem or retranslocation through the phloem from young to older leaves. This mechanism has been reported in many halophytes plants, and limit the transportation of salt to active younger leaves and reduce their toxic effect on such organs. The shedding of old leaves may then eliminate the excess of salt (Mian et al. 2011, Albert 1975). Likely, the initia decrement of gas exchange measures observed in this study for both species was generated by the salt osmotic stress, and was followed by a better acclimation and performances of $T$. jordanis than $T$. aphylla. The greater reduction of $g_{\mathrm{s}}$ observed under salt stress in T. aphylla (Fig. 1C-D) is consistent with the findings of Abbruzzese (2011), who reported a higher control of stomatal conductance in T. aphylla under salt stress. Differences in the recovery of stomatal opening may also account for the higher salt tolerance observed in $T$. jordanis as compared with $T$. aphylla. Stomata closure in the latter species may contribute to limit the damage under salt stress, thus reducing the assimilation rate, which increased the intrinsic water use efficiency $\left(A / g_{\mathrm{s}}\right)$, thereby maintaining a high biomass in the short period (Tab. 1) Contrastingly, $T$. jordanis showed a higher water use efficiency in absolute term.

The remarkable reduction of hexoses and starch in the leaves of $T$. aphylla under salt stress on the $2^{\text {nd }}$ day (Fig. 3A-C, Fig. 4) was associated with a decrease in $\mathrm{CO}_{2}$ assimilation, though the recover of the starch content to the same level of control plants was observed afterward. This could be related to both a partial recover of photosynthesis and a reduction of plant sinks demands, slowing down the plant height increment (Tab. 1), and decreasing sugar export according to the source/sink equilibrium under salt stress $(150 \mathrm{mM})$. The observed reduction of sugar content in T. aphylla confirm the results of Parida et al. (2004) who reported that salinity decreased soluble sugars in the salt tolerant mangrove Aegiceras corniculatum L., as well as those of Gadallah (1999) who observed a reduction of soluble sugars in Vicia faba L. On the contrary, the content of sugars in the leaves of $T$. jordanis was not significantly reduced under salt stress (Fig. 3BD, Fig. 4). The maintenance of sugars in $T$. jordanis and the higher content of starch under control and salty conditions may have a protective role on membranes. Carbohydrates such as soluble sugars (glucose, fructose, sucrose) affects osmoregulation, osmoprotection, carbon storage, and radical scavenging (Parida et al. 2002). Consistently with many other halophytes species (Flowers et al. 1986), T. jordanis growth was stimulated by salinity, while $T$. aphylla showed a growth reduction in the same experimental conditions (Tab. 1). Accordingly, Waisel (1961) reported a reduced growth of saplings of $T$. aphylla under irrigation with $0.1 \mathrm{M}$ and $0.2 \mathrm{M}$ of $\mathrm{NaCl}$. Such growth depression is probably due to the osmotic and toxic effect of the $\mathrm{NaCl}$ solution (Waisel 1961), which accumulated at higher concentration in $T$. aphylla than in T. jordanis (Abbruzzese 2011). Growth was also possibly reduced as a consequence of the increase in cost energy associated with salt pumping, increased respiration (Kleinkopf \& Wallace 1974) and decreased photosynthetic rates (Jackson et al. 1990).

In contrast to salt, drought $(50 \% \mathrm{FC})$ never induced appreciable effects on carbon assimilation in any of the studied species in the short time (Fig. 1). The maintenance of optimal levels of photosynthesis under drought conditions may be related to the high efficiency of Tamarix twigs to excrete calcium carbonate in non-saline soils, thereby trapping the $\mathrm{CO}_{2}$ from the atmosphere. According to Waisel (1991), a leaf chalk crust may have a conspicuous adaptive value in terms of optimization of photosynthesis by concentrating the atmospheric $\mathrm{CO}_{2}$. Despite its small surface area, $T$. aphylla showed a higher capacity of assimilation under control and drought stress (Fig. 1A-B). T. aphylla excrete more calcium than $T$. jordanis (Abbruzzese 2011), therefore it may benefit from an extra source of carbon trapped by calcium, and exploit it for optimal assimilation during early morning (Waisel 1991).

In this study, the stomatal conductance of plants grown under drought conditions was substantially maintained in both species over the whole experiment, except for day 7 (Fig. $1 \mathrm{C}-\mathrm{D})$, when an increase in soluble sugars and a concomitant decrease of relative humidity $(37.9 \%)$ was observed (Fig. 3A-F). Despite the short duration of the experiment carried out, the high content of soluble sugars and their increase mainly in $T$. aphylla suggest that soluble sugars accumulation is one of the possible mechanisms adopted by this species as a response to drought. Accumulation of soluble carbohydrates in leaves is common under water stress (Chaves 1991). Moreover, it has been reported that plants growing in dry habitats contain more soluble sugars than those living in moist habitats. 1ljin (1957) reported values of sugar content (on a dry weight basis) ranging from $1.3 \%$ in herbaceous mesophytes to $6.9 \%$ in xerophytic trees and shrubs. In this study, an increase of sucrose and a simultaneous decrease of starch content in plants grown under drought stress was detected on the $7^{\text {th }}$ day of the experiment (Fig. 3E-F, Fig. 4). It is also a common observation that water stress conditions induce a severe decrease in starch and simultaneously an accumulation of soluble sugars (lljin 1957, Turner et al. 1978). Such a shift in carbon partitioning may have an adaptive value, since it could contribute to osmotic adjustment and protection (Daie 1996, Lawlor \& Cornic 2002).

Despite the limited effect of drought on photosynthesis, growth of $T$. jordanis plants was severely limited, with height increment lower by $55 \%$ than that of control plants. This reduced growth may be due to other factors not analyzed in this study, such as hormones or precursors (Fricke et al. 2006, Munns et al. 2000). Contrastingly, the slight effect of drought on height increment and biomass of $T$. aphylla plants was probably due to the high and early increase of intrinsic water use efficiency in this species, allowing plants under stress conditions to produce a quantity of dry matter similar to control plants with less water consumption. Also, the increase in the root/shoot ratio observed in $T$. jordanis under drought conditions was probably due to a significant decrease in the shoot biomass (Tab. 1), that is considered an adaptive mechanism allowing to reduce the transpiration surface and to increase the water absorption from the soil (Joly et al. 1989).

Controversial results are reported in the literature about the combined effect of salt and drought stress. In this study, the presence of both constraints in the soil (salt 150 $\mathrm{mM}+$ drought $50 \% \mathrm{FC}$ ) showed the most severe impact on both species, as compared with water and salt stress applied separately. Symptoms of yellowing and defoliation in plants under such combined stress were much more evident than in leaves of plants grown under salt alone, appearing on the 
third day of the experiment. Such symptoms suggest a high accumulation of salt in older tissues to prevent the death of young leaves. Adverse effects on all measured parameters were reported. Photosynthesis, transpiration, stomatal conductance, sugars and starch content were significantly reduced in response to the combined stress. The combination of drought and salt stress induced effects similar to salt stress on the reduction of hexoses sugars. In addition, both species showed a marked decline of the starch content, which was lower than that of salt and drought applied alone. This confirms the positive interaction between salt and drought in the reduction of the starch content in the species analyzed. However, the ability of plants of both species to survive the whole experiment may be associated with a high production of proline content and with an increase of their water use efficiency. Proline may act as an osmoregulator, a ROS (reactive oxygen species) scavenger and a molecule chaperone reinforcing the structure of proteins, thereby protecting plant cells from damage caused by stress (Delauney \& Verma 1993, Krasensky \& Jonak 2012). Moreover, it has been sug gested that proline may represent a stock of nitrogen available for the plant after a period of suffering from water deficiency (Dib et al. 1992). In this study, a high proline content was observed in the two Tamarix species grown under the combined stress (Fig. 5) Likely, proline accumulation was induced by $\mathrm{NaCl}$ ion stress rather than drought, because plants grown under salt stress alone also showed an initial increase in proline content (Fig. 5). However, proline usually accumulates in the cytosol, which is only 5 to $10 \%$ of the cell volume (Lee et al. 1990, Winter et al. 1993). Based on our results, the contribution of proline to the cell osmotic potential (0.028-0.031 MPa at the $7^{\text {th }}$ day) was too low for the osmotic adjustement of the cytoso (0.2-0.4 MPa in osmotic potential). Therefore, we may hypothesize that proline acts mainly as osmoprotector and storage of nitrogen and carbon for future use under stressful conditions. These considerations are supported by Wikqiang et al. (2010) and Koyro (2006), who found that proline contributed to the protection of $T$. chinensis against high salinity in the soil by scavenging the ROS generated by salt stress, which may cause oxidative damage to membrane lipids, proteins and nucleic acids. Furthermore, the accumulation of proline was suggested to be related to a decrease or suppression of gene encoding for the proline dehydrogenase (PDH), or due to the expression of gene P5CS for the key enzyme regulating the proline synthesis via glutamate pathway under environmental stresses (Krasensky \& Jonak 2012).

In this study, the severe reduction of plant growth observed in both Tamarix species grown under high salinity and drought could be attributed to more than one factor: hindrance in cell division and cell elongation, reduction in assimilation rate and increase in ion toxicity due to reduction of water availability. All the above factors may retard plant elongation, but also hinder dry matter accumulation causing a decrease in biomass production.

\section{Conclusion}

The two species analyzed in this study, Tamarix aphylla and T. jordanis, proved their ability to cope with salt and drought stress to a different extent, through common acclimatization mechanisms. T. aphylla showed better performances and growth than $T$. jordanis under drought stress, due to higher photosynthesis, sugar accumulation and water use efficiency. The maintenance of an adequate sugar content under salt stress reflects the important role of these osmolytes in cell protection of salt tolerant species like $T$. jordanis. From an agronomic and environmental perspective, the two species studied seems to acclimatize fairly well to a moderate salinity $(150 \mathrm{mM})$ without any loss of biomass. In particular, $T$. jordanis seems to maintain a high efficiency in the carbon sequestration over a relatively short period of time. However, a reduction in biomass could be expected at moderate drought $(50 \% \mathrm{FC})$, particularly in $T$. jordanis. In soils with high salinity (0.1-0.2 $\mathrm{M}$ of $\mathrm{NaCl})$ and in the absence of irrigation, a short drought period might causes a severe damage to these trees.

\section{Acknowledgments}

The authors are grateful to the Euro Mediterranean Center for Climate Change (CMCC) and the Italian Ministry of Environmental, Land and Sea (MATTM) for providing financial support. The authors further acknowledge Matilde Tamantini at the University of Tuscia and Giovanni De Simone at the Institute of Agro-Environmental and Forest Biology (IBAF/CNR) for the technical support. We would like to thank also Rindala Hakim and Inaam Darwish for editing the English version of this paper.

\section{References}

Abbruzzese G (2011). Nuovi approcci in Tamarix spp. per l'identificazione tassonomica e la caratterizzazione funzionale in condizione si stress salino [New approaches for taxonomic identification and functional characterization of $\mathrm{Ta}$ marix spp. under salt stress conditions]. $\mathrm{PhD}$ Thesis, Università degli Studi della Tuscia, Viterbo, Italy, pp. 144.

Albert R (1975). Salt regulation in halophytes. Oecologia 21: 57-71. - doi: 10.1007/BF003458 93

Bar-Nun N, Poljakoff MA (1977). Salinity stress and the content of proline in roots of Pisum sativum and Tamarix tetragyna. Annals of Bota- ny 41 (1): 173-179. [online] URL: http://aob.oxfordjournals.org/content/41/1/173.short

Bates LS (1973). Rapid determination of free proline for water stress studies. Plant Soil 39: 205 207. - doi: 10.1007/BF00018060

Baum BR (1978). The genus Tamarix. Israel Academy of Sciences and Humanities, Jerusalem, Israel, pp. 209

Brotherson JD, Field D (1987). Tamarix: Impacts of a successful weed. Rangelands 9:110-112. [online] URL: http://journals.uair.arizona.edu/index.php/rangelands/article/download/12735/120 14\#page $=16$

Carman JG, Brotherson JD (1982). Comparisons of sites infested and not infested with saltcedar (Tamarix pentandra) and Russian olive (Elaeagnus angustifolia). Weed Science 30: 360-364. [online] URL: http://www.jstor.org/stable/4043 625

Chaves MM (1991). Effects of water deficits on carbon assimilation. Journal of Experimental Botany 42: 1-16. - doi: 10.1093/jxb/42.1.1

Crowe JH, Carpenter JF, Crowe LM, Anchordoguy TJ (1990). Are freezing and dehydration similar stress vectors? A comparison of modes of interaction of stabilizing solutes with biomolecules. Cryobiology 27: 219-231. - doi: 10.1016/ 0011-2240(90)90023-W

Daie J (1996). Metabolic adjustments, assimilate partitioning, and alterations in source-sink relations in drought-stressed plants. In: "Photoassimilate Distribution in Plant and Crops: SourceSink Relationships" (Zamski E, Schaffer AA eds). Marcel Dekker, New York, USA, pp. 407420. [online] URL: http://books.google.com/ books?id=Dv-ZvJuIC2UC

Delauney AJ, Verma DPS (1993). Proline biosynthesis and osmoregulation in plants. Plant Journal 4: 215-223. - doi: 10.1046/j.1365-313X.19 93.04020215.x

Dib TA, Monneveux P, Araus JL (1992). Adaptation à la sécheresse et notion d'ideotype chez le blé dur. II: Caractère physiologique d'adaptation [Drought adaptation and notion of ideotype in the durum wheat (Triticum durum Desf.). II. Physiological characters of adaptation]. Elsevier, INRA, Agronomie 12: 381-393. [in French] doi: 10.1051/agro:19920504

Ding F, Song J, Ruan Y, Wang BS (2009). Comparison of the effects of $\mathrm{NaCl}$ and $\mathrm{KCl}$ at the roots on seedling growth, cell death and the size, frequency and secretion rate of salt glands in leaves of Limonium sinense. Acta Physiologiae Plantarum 31: 343-350. - doi: 10.1007/s11738008-0240-9

Flowers TJ, Hajibagheri MA, Clipson NJW (1986). Halophytes. The Quarterly Review of Biology 61: 313-337. - doi: 10.1086/415032

Frasier GW, Johnsen TN (1991). 37 - Saltcedar (tamarisk). In: "Classification, distribution, ecology and control in noxious range weeds" (eds (James LF, Evans JO, Ralphs MH, Child RD eds). Westview Press, Boulder, CO, USA, pp. 377-386. [online] URL: http://www.tucson.ars.ag.gov/unit/publications/PDFfiles/827.pdf Fricke W, Akhiyarovam G, Wei W, Alexanders- 
son E, Miller A (2006). The short-term growth response to salt of the developing barley leaf. Journal of Experimental Botany 57: 1079-95. doi: 10.1093/jxb/erj095

Gadallah MAA (1999). Effects of proline and glycinebetaine on Vicia faba response to salt stress. Biologia Plantarum 42 (2): 249-257. - doi: 10.1023/A:1002164719609

Hoekstra FA, Golovina EA, Buitink J (2001) Mechanisms of plant desiccation tolerance. Trends in Plant Science 6 (9): 431-438. - doi: 10.1016/S1360-1385(01)02052-0

1ljin WS (1957). Drought resistance in plants and physiological processes. Annual Review of Plant Physiology 8: 257-274. - doi: 10.1146/annurev. pp.08.060157.001353

Jackson J, Ball JT, Rose MR (1990). Assessment of the salinity tolerance of eight Sonora desert riparian trees and shrubs. Final Report. Desert Research Institute, University of Nevada Biological Sciences Center, Reno, NE, USA, pp. 102.

Joly RJ, Adams WT, Stafford SG (1989). Phenological and morphological responses of mesic and dry site sources of coastal Douglas-fir to water deficit. Forest Science 35: 987-1005. [online] URL: http://www.ingentaconnect.com/content/ saf/fs/1989/00000035/00000004/art00009

Jones GP, Paleg LG, Waisel Y, Solomon A, Beer S (1995). Trans-3-hydroxy-N-methyl-1-proline hydrochloride. Acta Crystallographica 51: $287-$ 289. - doi: 10.1107/S0108768194013327

Jones GP, Naidu BP, Waisel Y, Solomon A, Paleg LG (2005). Occurrence of stress response of Nmethylproline compounds in Tamarix species. Phytochemistry 67: 156-160. - doi: 10.1016/j.phytochem.2005.10.027

Kleinkopf GE, Wallace A (1974). Physiological basis for salt tolerance in Tamarix spp. Plant Science Letters 3: 157-163. - doi: 10.1016/03044211(74)90071-6

Koyro HW (2006). Effect of salinity on growth, photosynthesis, water relations and solute composition of the potential cash crop halophyte Plantago coronopus (L.). Environmental and Experimental Botany 56: 136-146. - doi: 10.101 6/j.envexpbot.2005.02.001

Kozlowski TT (1997). Responses of woody plants to flooding and salinity. Tree Physiology Monograph 1: 1-29. [online] URL: http://www.pucrs. br/fabio/fisiovegetal/Encharcamento.pdf

Krasensky J, Jonak C (2012). Drought, salt, and temperature stress-induced metabolic rearrangements and regulatory networks. Journal of Experimental Botany 63: 1593-1608. - doi: 10.1093/ jxb/err460

Lawlor DW, Cornic G (2002). Photosynthetic carbon assimilation and associated metabolism in relation to water deficits in higher plants. Plant, Cell and Environment 25: 275-294. - doi: 10.1046/j.0016-8025.2001.00814.x
Lee RB, Ratcliffe RG, Southon TE (1990). ${ }^{31} \mathrm{P}$ NMR measurements of the cytoplasmic and vacuolar Pi content of mature maize roots: relationships with phosphorus status and phosphate fluxes. Journal of Experimental Botany 41: 10631078. - doi: 10.1093/jxb/41.9.1063

McClintock E (1951). Studies in California ornamental plants: 3. The tamarisks. Journal of California Horticultural society 12: 76-83.

Metcalfe CR, Chalk L (1950). Anatomy of the dicotyledons. Clarendon Press, Oxford, UK, pp. 1500. [online] URL: http://www.cabdirect.org/ abstracts/19510301202.html

Mian A, Senadheera P, Maathuis FJM (2011). Improving crop salt tolerance: anion and cation transporters as genetic engineering targets. Plant stress 1: 64-72. [online] URL: http://www.researchgate.net/publications/0912f503bc04f6b94 0000000.pdf

Moscatello S, Famiani F, Proietti S, Farinelli D, Battistelli A (2011). Sucrose synthase dominates carbohydrate metabolism and relative growth rate in growing kiwifruit (Actinidia deliciosa cv Hayward). Scientia Horticulturae 128 (3): 197205. - doi: 10.1016/j.scienta.2011.01.013

Mounsif M, Wan C, Sosebee R (2002). Effects of top-soil drying on saltcedar photosynthesis and stomatal conductance. Journal of Range Management 55 (1): 88-93. - doi: 10.2307/4003268

Munns R, Guo J, Passioura JB, Crame GR (2000). Leaf water status controls day-time but not daily rates of leaf expansion in salt-treated barley. Australian Journal of Plant Physiology 27: 949-957. [online] URL: http://www.publish.csiro.au/paper/PP99193

Parida AK, Das AB, Das P (2002). NaCl stress causes changes in photosynthetic pigments, proteins and other metabolic components in the leaves of a true mangrove, Bruguiera parviflora, in hydroponic cultures. Journal of Plant Biology 45: 28-36. - doi: 10.1007/BF03030429

Parida AK, Das AB, Sanada Y, Mohanty P (2004). Effects of salinity on biochemical components of the mangrove, Aegiceras corniculatum. Aquatic Botany 80 (2): 77-87. - doi: 10.101 6/j.aquabot.2004.07.005

Ramadan T (1998). Ecophysiology of salt excretion in the xero-halophyte Reaumuria hirtella. Plant Phytologist 139: 273-281. - doi: 10.1046/ j.1469-8137.1998.00159.x

Rodman J (1990). Reflections on tamarisk bashing. In: Proceedings of the " 1 st Annual Meeting of the Society of Ecological Restoration Restoration '89: the new management challenge" (Hughes HG, Bonnicksen TM eds). Oakland (CA, USA) 16-20 Jan 1989. The University of Wisconsin Arboretum, Society for Ecological Restoration, Madison, WI, USA, pp. 59-68.

Scholander PF, Hammel HT, Hemmingsen EA, Bradstreet ED (1964). Hydrostatic pressure and osmotic potential in leaves of mangroves and some other plants. Proceedings of the National Academy of Sciences USA 52 (1): 119-125. doi: 10.1073 /pnas.52.1.119

Scholander PF, Hammel HT, Brastreer ED, Hemmingsen EA (1965). Sap pressure in vascular plants. Science 148: 339-346. - doi: 10.1126/science.148.3668.339

Solomon A, Beer S, Waisel Y, Jones GP, Paleg LG (1994). Effects of $\mathrm{NaCl}$ on the carboxylating activity of Rubisco from Tamarix jordanis in the presence and absence of proline-related compatible solutes. Physiologia Plantarum 90: 198-204. - doi: 10.1111/j.1399-3054.1994.tb02211.x

Turner NC, Begg JE, Tonnet ML (1978). Osmotic adjustment of sorghum and sunflower crops in response to water deficits and its influence on the water potentials at which stomata close. Functional Plant Biology 5 (5): 597-608. [online] URL: http://www.publish.csiro.au/paper/PP 9780597

Vertucci CW, Farrant JM (1995). Acquisition and loss of desiccation tolerance: In: "Seed Development and Germination" (Kigel J, Galil G eds). Marcel Dekker, New York, USA, pp 237-272. [online] URL: http://books.google.com/books? id=AHVDtveqlpMC

Waisel Y (1961). Ecological studies on Tamarix aphylla (L.) Karst. III. The salt economy. Plant soil 4: 356-364.

Waisel Y (1972). Biology of halophytes. Academic Press, New York, USA, pp. 410. [online] URL: http://books.google.com/books?id=BKy4ij5cT9gC

Waisel Y (1991). The salt glands of Tamarix aphylla: a system for salt recretion or for carbon concentration? Physiologia Plantarum 83:506510. - doi: 10.1111/j.1399-3054.1991.tb00127.x Wikqiang L, Ajmal Khan M, Zhang X, Liu X (2010). Rooting ad shoot growth of stem cuttings of saltcedar (Tamarix chinensis Lour) under salt stress. Pakistan Journal of Botany 42 (6): 41334142 .

Wildburger C (2004). Afforestation and reforestation for climate change mitigation: potentials for pan European action. Programme Office for Central Europe, Gland, Switzerland, pp. 12. [online] URL: http://www.foresteurope.org/filestore/ foresteurope/Meetings/2006/unf/Afforestation.pd $\mathrm{f}$

Winter H, Robinson DG, Heldt HW (1993). Subcellular volumes and metabolite concentrations in barley leaves. Planta 191: 180-190. - doi: 10.1007/BF00199748

Zlatnik E (1999). Juniperus osteosperma. In: "Fire Effects Information System". Fire Sciences Laboratory, Rocky Mountain Research Station, USDA Forest Service, USA, pp. 31. [online] URL: http://www.fs.fed.us/database/feis/plants/ tree/junost/all.html 